\title{
Ny norsk terskelverdi for verdien av et godt leveår?
}

\author{
Stortinget har vedtatt at terskelverdien for verdien av et godt leveår skal basere seg på «nytten for andre \\ pasienter som ellers kunne ha vært realisert med de samme ressursene». En britisk forskningsgruppe har \\ nå laget et estimat for hva denne terskelverdien kan være i Norge.
}

Prioritering innen helsetjenesten har vært et offentlig tema i over 30 år, og kostnadseffektivitet har stått sentralt de siste $20 \mathrm{av}$ disse årene (1). Som påpekt av Grundutvalget er det et gap mellom hva som er mulig å innføre i helsetjenesten, og hva som er økonomisk og etisk forsvarlig (2). Kostnadseffektivitet er ett av flere verktøy som kan hjelpe oss i prioriteringen. Hensikten er å få mest mulig helse ut av hver krone som allerede er bevilget til helsetjenesten. For at kostnadseffektivitet skal være brukbart i praksis, er man avhengig av en såkalt terskelverdi. En slik terskelverdi bør ideelt sett være estimert ut fra norske data, men dette arbeidet er foreløpig ikke gjort.

\section{Foreløpige estimater}

Professor emeritus Ivar Sønbø Kristiansen har stått sentralt i den norske debatten om terskelverdi. I 2002 foreslo han å bruke bruttonasjonalprodukt per innbygger for Norge, som den gang var på ca. 350000 kroner, for «et godt leveår» (1). Med «et godt leveår» mente han kvalitetsjustert leveår (quality-adjusted life-year, QALY). Debatten har senere fått flere oppsving, både da tidligere helsedirektør Bjørn Inge Larsen bekreftet at man tenkte på verdier i størrelsesorden 500000 kroner per kvalitetsjusterte leveår som terskelverdi (3), og nå senest i kjølvannet av prioriteringsutvalgets forslag i 2014 om å bruke et omregnet estimat fra Storbritannia inntil man har verdier basert på norske data $(4,5)$. Terskelverdien som ble estimert i Storbritannia, var basert på logikken om «alternativkostnad», som kort fortalt går ut på at ressurser som brukes til nye tiltak, tas fra annen behandling, og at man derfor taper helse et annet sted i helsevesenet når et nytt tiltak innføres.

Da prioriteringsmeldingen ble godkjent i Stortinget høsten 2016, var estimatet fra prioriteringsutvalget omtalt som 275000 kroner per gode leveår. Prioriteringsutvalget forholdt seg imidlertid ikke konsekvent til 275000 kroner som terskelverdi, som man kan ha fått inntrykk av i ettertid, men verdiene 215000 kroner, 250000 kroner og 275000 kroner litt om hverandre.

Etter fremlegging av prioriteringsutvalgets arbeid (4) har estimatet på 275000 kroner fått stor omtale og er nå også godkjent av Stortinget. Det er derfor verdt å merke seg at miljøet som opprinnelig regnet seg frem til en alternativkostnad for Storbritannia, som prioriteringsutvalget baserte sine tall på, nå har kommet med et nytt forslag for flere land, deriblant Norge (6). Verdiene de skisserer, ligger mellom 43000 dollar og 94000 dollar per kvalitetsjusterte leveår, litt avhengig av utregningsmåte.

\section{Omregning til norske kroner}

Hva slags alternativkostnad gir de nye britiske beregningene, omregnet til norske kroner? Siden Woods og kolleger (4) bruker amerikanske dollar fra 2013, bør man

\section{«Hensikten er å få mest mulig helse ut av hver krone»}

omregne med gjennomsnittlig valutakurs for 2013 (7). Alternativkostnad for 2013 omregnet fra dollar ligger da mellom 253000 kroner og 551000 kroner. Beløpet for 2017 kan beregnes ved hjelp av endringer $i$ «husholdningenes disponible realinntekt», som anbefalt i Helsedirektoratets retningslinjer fra 2012 (8). Dette medfører at terskelverdi for Norge bør ligge mellom 277000 kroner og 602000 kroner for 2017

Variasjonen i Woods' angivelse av alternativkostnad skyldes noe som kalles «inn tektselastisitet» (4). I retningslinjene fra Helsedirektoratet (8) foreslås det å bruke en elastisitet på 1,25. Det norske estimatet for 2017 blir da på 385721 kroner per kvalitetsjusterte leveår. Legemidler godkjent av Legemiddelverket og Helsedirektoratets beslutningsforum for nye metoder har de seneste årene vært basert på en terskelverdi rundt 700000 kroner per kvalitetsjusterte leveår (9), om lag det dobbelte av dette estimatet. Hvis man innfører tiltak med kostnad per vunnet kvalitetsjustert leveår rundt 700000 kroner, betyr dette at for hvert «gode leveår» man vinner, vil man i gjennomsnitt miste to gode leveår for andre pasienter - hvis nye tiltak finansieres over et allerede besluttet helsebudsjett for inneværende år.

Inntil man har estimert på bakgrunn av norske data hvor mye helse som går tapt for hver krone som omprioriteres i det norske helsevesenet, foreslår jeg at vi, basert på de nye beregningene fra Storbritannia, bruker terskelverdien 385721 kroner per kvalitetsjusterte leveår i 2017. Omregning til andre år kan følge retningslinjer gitt av Helsedirektoratet.

\section{Torbjørn Wisløff \\ twisloff@gmail.com}

Torbjørn Wisløff (f. 1976) er statistiker og helse$ø$ konom. Han er seniorforsker ved Folkehelseinstituttet og førsteamanuensis ved Universitetet i Oslo. I tillegg leder han gruppen for metodeutvikling innen helseøkonomisk evaluering i Society for Medical Decision Making. Forfatter har fylt ut ICMJE-skjemaet og oppgir følgende interessekonflikter: Han har mottatt honorar fra Oslo Economics og Biogen.

\footnotetext{
Litteratur

1. Wisløff T. Prioriteringskriterier i helsetjenesten. Tidsskr Nor Legeforen 2015; 135: 1373-5.

2. Norges offentlige utredninger. Piller, prioritering og politikk. NOU 1997: 7. https://regjeringen.no/ no/dokumenter/nou-1997-7/id140767/sec1 (2.3.2017).

3. Norges offentlige utredninger. Åpent og rettferdig - prioriteringer i helsetjenesten. NOU 2014: 12. https://regjeringen.no/no/dokumenter/ NOU-2014-12/id2076730/sec1 (2.3.2017)

4. Aftenposten forside. For dyrt å redde alvorlig syke. Aftenposten 3.12.2008.

5. Claxton K, Martin S, Soares M et al. Methods for the estimation of the National Institute for Health and Care Excellence cost-effectiveness threshold. Health Technol Assess 2015; 19: 1-503, v-vi.

6. Woods B, Revill P, Sculpher M et al. Country-level cost-effectiveness thresholds: initial estimates and the need for further research. Value Health 2016; 19: 929-35

7. Norges Bank. Valutakurser. http://norges-bank.no/ Statistikk/Valutakurser/ (28.2.2017)

8. Sælensminde K, Torkilseng E. Samfunnsøkonomiske analyser i helsesektoren - en veileder. Oslo: Helsedirektoratet, 2011

9. Foss P. Legemiddelindustriens syn på helseøkonomi. Dagens Medisin Arena 3.5.2016. https//dagensmedisin.no/contentassets/ f357a41694964ae6b044c61b2578b7ea/ presentasjon-petter-foss-dm-arena03.05.2016.pdf (28.2.2017)
}

Mottatt 7.2. 2017, første revisjon innsendt 21.2. 2017, godkjent 2.3. 2017. Redaktør: Kari Tveito.

Publisert først på nett. 